\title{
Altmetric Versus Bibliometric Perspective Regarding Publication Impact and Force
}

\author{
Arfon G. M. T. Powell ${ }^{1}$ Victoria Bevan ${ }^{2} \cdot$ Chris Brown $^{2} \cdot$ Wyn G. Lewis ${ }^{2}$
}

Published online: 13 March 2018

(C) The Author(s) 2018

\begin{abstract}
Background Bibliometric and Altmetric analyses highlight key publications, which have been considered to be the most influential in their field. The hypothesis was that highly cited articles would correlate positively with levels of evidence and Altmetric scores (AS) and rank.

Methods Surgery as a search term was entered into Thomson Reuter's Web of Science database to identify all English-language full articles. The 100 most cited articles were analysed by topic, journal, author, year, institution, and AS.

Results By bibliometric criteria, eligible articles numbered 286,122 and the median (range) citation number was 574 (446-5746). The most cited article (Dindo et al.) classified surgical complications by severity score (5746 citations). Annals of Surgery published most articles and received most citations $(26,457)$. The country and year with most publications were the USA $(n=50)$ and $1999(n=11)$. By Altmetric criteria, the article with the highest AS was by Bigelow et al. (AS $=53$, hypothermia's role in cardiac surgery); Annals of Surgery published most articles, and the country and year with most publications were USA $(n=4)$ and $2007(n=3)$. Level-1-evidence articles numbered 13, but no correlation was found between evidence level and citation number (SCC 0.094, $p=0.352$ ) or AS (SCC = $0.149, p=0.244)$. Median AS was $0(0-53)$, and in articles published after the year 2000, AS was associated with citation number $(r=0.461, p=0.001)$ and citation rate index $(r=0.455, p=0.002)$. AS was not associated with journal impact factor $(r=0.160, p=0.118)$.

Conclusion Bibliometric and Altmetric analyses provide important but different perspectives regarding article impact, which are unrelated to evidence level.
\end{abstract}

Electronic supplementary material The online version of this article (https://doi.org/10.1007/s00268-018-4579-9) contains supplementary material, which is available to authorized users.

Arfon G. M. T. Powell

powella16@cardiff.ac.uk

1 Division of Cancer and Genetics, University Hospital of Wales, Cardiff University, Heath Park, Cardiff, UK

2 Wales Deanery School of Surgery, Cardiff University, Heath Park, Cardiff, UK

\section{Introduction}

Any reasonable observer might assume that the 100 most cited articles in surgery represent classic, landmark, or marquee communications. Certainly, the number of times articles are cited is used widely to measure the impact of journals and assess the quality of authors' contributions. Yet it has been reported that among such best seller lists exist articles relating to topics that were "hot" or popular at one time and then faded. As time passes, even true classics are arguably cited less frequently, because their substance has been absorbed into the received wisdom of the 
literature - a phenomenon described as obliteration by incorporation.

A reference is the acknowledgment that one article gives to another; a citation is the acknowledgement that one article receives from another. Citation analysis is that area of bibliometrics that deals with the study of these relations. Citation analysis involves ranking and evaluating an article or journal based on the number of citations it receives. The establishment of a citation rank list identifies published work that has had the greatest intellectual influence. In addition to determining the most frequently cited articles, this analysis is also used to rank journals in terms of impact [1]. Many medical specialties have utilized citation rank analysis to identify the most influential papers in their field which include trauma and orthopaedic surgery [2], general surgery [3, 4], emergency general surgery [5], and oncology [6].

Citations take time to accumulate, and other, faster assessment means have emerged recently which has led to the development of alternative metrics, or "Altmetrics". These extend the concept of citation beyond references in other scientific papers; by recording, for example, how often a paper is downloaded, or when the outcome of a clinical trial is used to develop guidelines for doctors, or if a piece of work is included in a course curriculum. To date, no study has undertaken to determine the most influential articles in the global field of surgery and to compare the relative value of citation number, with level of evidence or Altmetric score (AS). The aim of this study, therefore, was to determine the areas of translational surgical research that have been most influential in driving advances in the art and science of surgery, not only to identify what makes a surgical article citable, but also to develop what might arguably constitute an all-time surgical must-do reading list. The hypotheses were: firstly, higher citation number and rank would correlate positively with higher levels of evidence than lower citation number and rank; secondly, AS and rank would correlate with citation number and rank, after a certain critical publication date, given that organisations such as "twitter" have only been in existence since 2006.

\section{Methods}

A search of the Thomson Reuters Web of Science citationindexing database and research platform was completed using the search term Surgery. The returned dataset was filtered to include only English-language and full articles and sorted by number of citations; a method initially developed by Paladugu et al. [3]. The 100 most cited articles were identified from the large number of manuscripts returned. The dataset was then further evaluated examining title, first and senior author, institution and department of the first author, topic, specialty, year of publication, and the country of origin. The 5-year impact factor (for the year 2015) of each journal publishing the articles was recorded. The quality of evidence contained within the articles was assessed according to the Sackett scoring system [7] and the Oxford Evidence Based Medicine scoring system [8]. Altmetric scores were obtained by downloading the "Altmetric it" function from the Altmetric.com website (https://www.altmetric.com/products/ free-tools/bookmarklet/) and analysed by utilising the journal article page containing the doi reference number.

\section{Results}

The Web of Science search returned 286,122 full-length, English-language articles. Table 1 lists the 100 most cited articles [9-108]. The number of citations ranged from 5746 for Dindo et al. [9] to 446 for Kennedy et al. [108]. The median citation was 574 [interquartile range (IQR) 354.8-792.3], which was not normally distributed. The oldest article featured in the top 100 was by Bigelow et al. [69]. The most recent article was by Clavien et al. [13].

The 100 most cited articles were published in 30 journals with the number of articles per journal ranging from 1 to 32 (Table 2). Annals of Surgery not only published the most articles $(n=32)$, but also received the most citations $(26,457)$. Annals of Surgery had the highest impact factor of 8.6, with a 5-year impact factor of 8.7.

The country and year with the most articles in the top 100 was the USA with 50 and $1999(n=11)$, followed by France with 8 and $2004(n=9)$. The institution with the most citations was the University of Zurich with 7644 across 3 articles (supplementary Table 1). The Memorial Sloan-Kettering Cancer Center and Washington University had the highest number of articles in the top 100 with 4 (supplementary Table 1). Seven authors had 2 first author articles in the top 100 with the highest citation index of 2312.

The commonest related specialty to feature in the top 100 was hepato-pancreatico-biliary surgery with 15 articles. This was followed by Trauma \& Orthopaedic surgery ( $n=13)$, and Cardiothoracic surgery $(n=11)$, respectively (supplementary Table 2). The specialties with the fewest articles in the top 100 were Ophthalmology, Plastic surgery, and Urology, with one each. The most common topic to feature in the top 100 was management of surgical disease with 53 articles, which included 14 (26\%) randomised control trials (supplementary Table 3 ). The second commonest topic was the identification, classification and management of surgical complications with 16 articles. 
Table 1 The top 100 cited papers in surgery

\begin{tabular}{|c|c|c|c|c|c|}
\hline Rank & Citations & First author & Rank & Citations & First author \\
\hline 1 & 5746 & D Dindo & 51 & 571 & JD Cooper \\
\hline 2 & 1756 & Y Fong & 52 & 567 & TP Grantcharov \\
\hline 3 & 1704 & SAM Nashef & 53 & 567 & PF Sharkey \\
\hline 4 & 1575 & RB Rutherford & 54 & 560 & HG Willert \\
\hline 5 & 1437 & PA Clavien & 55 & 560 & K Maruyama \\
\hline 6 & 1242 & NF Kassell & 56 & 556 & YM Fong \\
\hline 7 & 1220 & RJ Heald & 57 & 549 & DA Luce \\
\hline 8 & 1168 & L Norgren & 58 & 541 & O Dworak \\
\hline 9 & 1130 & NE Seymour & 59 & 538 & WG Bigelow \\
\hline 10 & 1089 & A Carpentier & 60 & 535 & TH Rockwood \\
\hline 11 & 1063 & M Lacroix & 61 & 527 & KJ Jenkins \\
\hline 12 & 992 & DN Krag & 62 & 526 & JR Steadman \\
\hline 13 & 926 & JA Martin & 63 & 524 & TM Pawlick \\
\hline 14 & 853 & F Rogues & 64 & 517 & R Reznick \\
\hline 15 & 833 & SF Khuri & 65 & 516 & DL Morton \\
\hline 16 & 811 & G Gugliemi & 66 & 516 & LL Creswell \\
\hline 17 & 800 & R Earlam & 67 & 511 & WE Enker \\
\hline 18 & 784 & LV Laitinen & 68 & 510 & J Marescaux \\
\hline 19 & 769 & SA Curley & 69 & 505 & SS Burkhart \\
\hline 20 & 754 & PR Schauer & 70 & 504 & H Kehlet \\
\hline 21 & 753 & JM Porter & 71 & 502 & JC Cheville \\
\hline 22 & 751 & RJ Heald & 72 & 500 & P Borgstein \\
\hline 23 & 740 & R Adam & 73 & 499 & I Ciric \\
\hline 24 & 733 & JR Siewert & 74 & 491 & AC Wittgrove \\
\hline 25 & 711 & L Norgren & 75 & 491 & PM Black \\
\hline 26 & 697 & LG Svensson & 76 & 488 & KCMJ Peeters \\
\hline 27 & 690 & LM Galatz & 77 & 488 & D Rattner \\
\hline 28 & 687 & JH Klinkenbijl & 78 & 486 & J Bernier \\
\hline 29 & 686 & VW Fazio & 79 & 486 & LH Edmunds \\
\hline 30 & 679 & B Eklof & 80 & 484 & K Slim \\
\hline 31 & 674 & NV Christou & 81 & 484 & BW Lytle \\
\hline 32 & 668 & ED Arrington & 82 & 484 & KC Conlon \\
\hline 33 & 665 & AL Benabid & 83 & 483 & T Kajitani \\
\hline 34 & 659 & G Knutsen & 84 & 480 & RMH Roumen \\
\hline 35 & 657 & SM Strasberg & 85 & 475 & JH Balcom \\
\hline 36 & 646 & F Vinuela & 86 & 472 & A Habr-Gama \\
\hline 37 & 645 & SA Rosenberg & 87 & 467 & RM Rosenfeld \\
\hline 38 & 631 & H Bismuth & 88 & 466 & JA Sosa \\
\hline 39 & 622 & PA Clavien & 89 & 465 & JM Becker \\
\hline 40 & 620 & B Brandstrup & 90 & 461 & C Gerber \\
\hline 41 & 618 & O Ethgen & 91 & 460 & BE Bierbaum \\
\hline 42 & 614 & MN Wente & 92 & 458 & CW le Roux \\
\hline 43 & 613 & GP Buzby & 93 & 458 & DJ Gouma \\
\hline 44 & 605 & PR Schauer & 94 & 457 & P Boileau \\
\hline 45 & 604 & NF Kassell & 95 & 452 & CGS Huscher \\
\hline 46 & 600 & H Kehlet & 96 & 449 & CK Zarins \\
\hline 47 & 595 & J Butler & 97 & 448 & EH Oldfield \\
\hline 48 & 593 & MS Chen & 98 & 446 & L Hangody \\
\hline
\end{tabular}


Table 1 continued

\begin{tabular}{lccccc}
\hline Rank & Citations & First author & Rank & Citations & First author \\
\hline 49 & 581 & AP Furnary & 99 & 446 & M Minagawa \\
50 & 576 & NT Nguyen & 100 & 446 & DW Kennedy \\
\hline
\end{tabular}

Table 2 Journals with the top 100 cited surgery articles

\begin{tabular}{|c|c|c|c|}
\hline Journal title & $\begin{array}{l}5 \text {-year impact } \\
\text { factor }\end{array}$ & $\begin{array}{l}\text { Number of articles in the top } \\
100\end{array}$ & $\begin{array}{l}\text { Number of } \\
\text { citations }\end{array}$ \\
\hline Annals of Surgery & 8.7 & 32 & 26,457 \\
\hline Journal of Neurosurgery & 3.5 & 8 & 6263 \\
\hline Journal of Bone and Joint Surgery & 5.4 & 8 & 4351 \\
\hline Journal of Vascular Surgery & 3.3 & 6 & 5321 \\
\hline British Journal of Surgery & 5.8 & 4 & 3513 \\
\hline Journal of Thoracic and Cardiovascular Surgery & 3.5 & 4 & 2671 \\
\hline Annals of Thoracic Surgery & 3.3 & 4 & 2178 \\
\hline Journal of the American College of Surgeons & 5.1 & 4 & 2133 \\
\hline Archives of Surgery & 4.9 & 3 & 1736 \\
\hline American Journal of Surgery & 2.6 & 3 & 1730 \\
\hline European Journal of Cardiothoracic Surgery & 2.7 & 2 & 2557 \\
\hline Surgery & 3.7 & 2 & 1236 \\
\hline Clinical Orthopaedics and Related Research & 3.5 & 2 & 1235 \\
\hline Arthroscopy-The Journal of Arthroscopic and Related Surgery & 3.9 & 2 & 1031 \\
\hline Neurosurgery & 3.3 & 2 & 990 \\
\hline Surgical Oncology & 3.2 & 1 & 992 \\
\hline European Journal of Vascular and Endovascular Surgery & 3.0 & 1 & 711 \\
\hline World Journal of Surgery & 2.8 & 1 & 560 \\
\hline Journal of Cataract and Refractive Surgery & 3.1 & 1 & 549 \\
\hline International Journal of Colorectal Disease & 2.4 & 1 & 541 \\
\hline Diseases of the Colon and Rectum & 3.8 & 1 & 535 \\
\hline American Journal of Surgical Pathology & 5.1 & 1 & 502 \\
\hline Obesity Surgery & 3.4 & 1 & 491 \\
\hline Surgical Endoscopy and Other Interventional Techniques & 3.5 & 1 & 488 \\
\hline $\begin{array}{l}\text { Head and Neck-Journal for the Sciences and Specialties of the Head } \\
\text { and Neck }\end{array}$ & 2.8 & 1 & 486 \\
\hline ANZ Journal of Surgery & 1.3 & 1 & 484 \\
\hline Japanese Journal of Surgery & N/A & 1 & 483 \\
\hline Otolaryngology—Head and Neck Surgery & 2.1 & 1 & 467 \\
\hline Archives of Otolaryngology_-Head and Neck Surgery & 2.3 & 1 & 446 \\
\hline
\end{tabular}

N/A not available

Of the 14 randomised control trials, 8 related to the management of cancer, 2 related to the management of aneurysmal disease, 2 related to the use of laparoscopic bariatric procedures, 1 article related to the management of post-operative adhesions, and 1 compared autologous chondrocyte implantation with arthroscopic microfracture in patients with full-thickness traumatic defects of the knee. Of those articles related to cancer, colorectal cancer ( $n=12$ ) was the most prevalent followed by gastric cancer $(n=4)$. The median citation of the clinical trials was 504 (IQR 351.0-656.0) with a range of 687 to 446 compared with 588.0 (IQR 336.3-839.8) with a range of 5746 to 446 , $p=0.031$ for non clinical trials (supplementary figure 1).

Evidence levels of the included articles were initially scored using the Sackett scoring method [7]. Three were level 1 evidence, 12 were level 2 evidence, 18 were level 3 evidence, 25 were level 4 evidence, 28 were level 5 evidence, and 14 were not scored as they were guidelines or 
consensus statements. There was no relationship between the quality of evidence and the median number of citations received ( $p=0.674$, supplementary figure 2 ). The median number of citations received for each evidence level was: level 1 studies 488.00 (range 486.00-516.00), level 2 584.50 (IQR 449.00-766.25), level 3604.50 (IQR 458.00-879.25), level 4556.00 (IQR 446.00-798.00) and level 5554.50 (IQR 446-919.50) (supplementary figure 2). A possible limitation of the Sackett scoring system is that a well-designed prognostic study is still a cohort study that is considered low-level evidence. Therefore, the studies were also scored using the Oxford Evidence Based Medicine scoring system [8]. Studies were grouped as either therapeutic/aetiology $(n=69)$ or prognostic $(n=25)$. With regard to therapeutic/aetiology studies, there was no difference in the median number of citations received for each evidence level. The median for level $1(n=10)$ was 546.00 , level $2(n=8)$ was 559.00 , level $3(n=1)$ was 587.00 , level $4(n=40)$ was 587.50, and level $5(n=10)$ was 668.00 ( $p=0.444$ ) (Fig. 1). For prognostic studies, there was a difference in the median number of citations received for each evidence level. The median for level 1 $(n=3)$ was 853.00 , level $2(n=12)$ was 525.00 , level 3 $(n=2)$ was 498.00 , level $4(n=4)$ was 655.50 , and level 5 $(n=4)$ was 549.50 ( $p=0.393)$ (Fig. 1).

To test for a correlation between citations and evidence levels, the number of citations variable was grouped into deciles to meet the assumptions of the Spearman's correlation coefficient (SCC) test. There was no significant correlation between number of citations and the Oxford

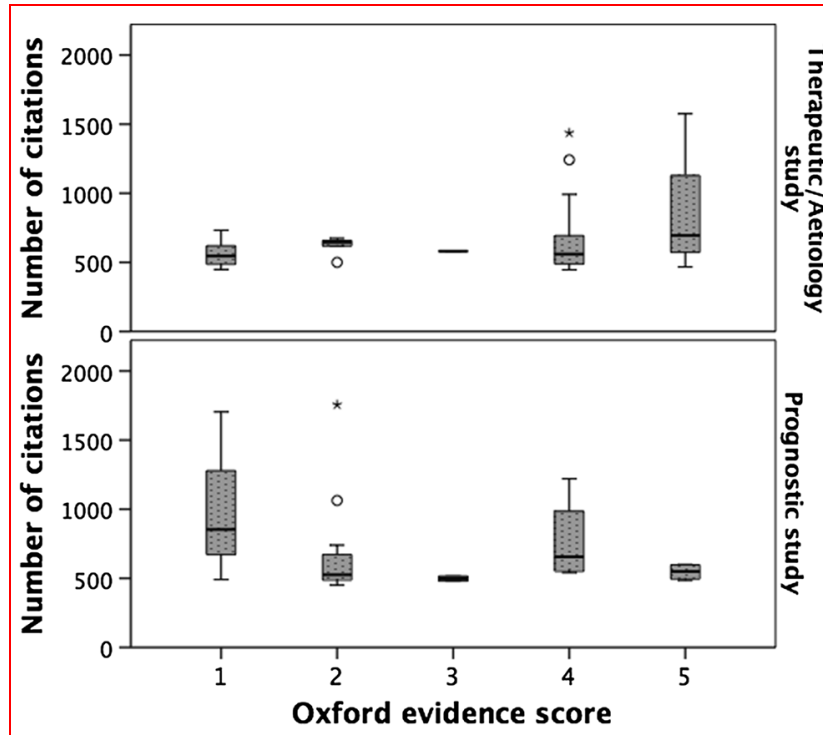

Fig. 1 The relationship between evidence level and number of citations in manuscripts stratified by study type. *Therapeutic/ aetiology studies $p=0.444$ Kruskal-Wallis test. Prognostic studies $p=0.393$ Kruskal-Wallis test evidence level (SCC 0.094, $p=0.352$ ). When therapeutic/ aetiology studies were analysed, there was a weak statistical association between low evidence level and higher citation number (SCC 0.233, $p=0.054$ ); however, this was not evident for prognostic studies (RCC - 0.012, $p=0.955)$.

A possible limitation of this type of study is that historical articles may accrue a larger number of citations despite lacking the impact of newer articles. To control for this, the number of citations were divided by the number of years since publication to give a citation rate index (CRI) (Table 3) [9-13, 15, 16, 19, 33, 50]. The CRI for the top 10 articles ranged from 442.00 for Dindo et al. [9] to 61.40 for Wente et al. [50]. The USA had the most articles in the top 10 CRI with 4, followed by Sweden and Switzerland with 2 each. Management of complications $(n=3)$ and consensus statements on the management of peripheral vascular disease $(n=3)$ were the commonest topics in the top $10 \mathrm{CRI}$. The citation rate analysis for clinical trials ranged from 53.91 to 18.43 compared with 442.00 to 8.03 for all 100 articles studied.

Altmetric scores ranged from 0 to 53 (median 0) with 40 articles scoring $\geq 1.0$. The article with the highest AS was by Bigelow et al. [69] (Table 4). The USA had the most articles in the top 10 AS with 4 , followed by Canada and Sweden with 2 each. Clinical guidelines $(n=3)$ were the commonest topic in the top $10 \mathrm{AS}$, followed by characterisation and management of complications $(n=2)$. Articles published from the year 2000 onwards had a significantly higher AS ( $p=0.018$ ) with a median of 1.0 (IQR 0.0-9.0), compared with a median of $0.0(0.0-1.0)$ in articles published before 2000 (Fig. 2). AS correlated with citation rate index $(r=0.266, p=0.008)$, but not with total number of citations $(r=0.179, p=0.079)$. In articles published after 2000, AS was associated with number of citations $(r=0.461, p=0.001)$, and citation rate index ( $r=0.455, p=0.002$ ). This correlation was not evident in articles published before 2000 for number of citations ( $r=0.085, p=0.548)$ or for citation rate index ( $r=0.075$, $p=0.595$, Fig. 3). Twenty-three articles appeared in both the top 40 for citations and AS. AS was not associated with evidence level when grouped as therapeutic/aetiology studies (SCC $=0.149, p=0.244$ ), prognostic studies (SCC $-0.277, p=0.197)$, or journal impact factor $(r=0.160$, $p=0.118)$.

\section{Discussion}

Periodical journals have been the principal means of disseminating scientific research since the seventeenth century, with the oldest still in existence, the Philosophical Transactions of the Royal Society, appearing first in 1665. 
Table 3 Top 10 articles with the highest citation rate

\begin{tabular}{|c|c|c|c|c|c|c|}
\hline Rank & $\begin{array}{l}\text { Citation } \\
\text { rate }\end{array}$ & First author & $\begin{array}{l}\text { Senior } \\
\text { author }\end{array}$ & Title & Institution & Country \\
\hline 1 & 442.00 & D. Dindo & PA. Clavien & $\begin{array}{l}\text { Classification of surgical complications-A new proposal } \\
\text { with evaluation in a cohort of } 6336 \text { patients and results of } \\
\text { a survey }\end{array}$ & $\begin{array}{l}\text { University of } \\
\text { Zurich }\end{array}$ & Switzerland \\
\hline 2 & 179.63 & PA. Clavien & $\begin{array}{l}\text { M. } \\
\text { Makuuchi }\end{array}$ & $\begin{array}{l}\text { The Clavien-Dindo Classification of Surgical Complications } \\
\text { Five-Year Experience }\end{array}$ & $\begin{array}{l}\text { University of } \\
\text { Zurich }\end{array}$ & Switzerland \\
\hline 3 & 116.80 & L. Norgren & CD. Liapis & $\begin{array}{l}\text { Inter-society consensus for the management of peripheral } \\
\text { arterial disease (TASC II) }\end{array}$ & $\begin{array}{l}\text { Orebro } \\
\quad \text { University }\end{array}$ & Sweden \\
\hline 4 & 97.56 & Y. Fong & $\begin{array}{l}\text { LH. } \\
\text { Blumgart }\end{array}$ & $\begin{array}{l}\text { Clinical score for predicting recurrence after hepatic } \\
\text { resection for metastatic colorectal cancer-Analysis of } \\
1001 \text { consecutive cases }\end{array}$ & $\begin{array}{l}\text { Memorial Sloan- } \\
\text { Kettering } \\
\text { Cancer Center }\end{array}$ & USA \\
\hline 5 & 94.67 & $\begin{array}{l}\text { SAM. } \\
\text { Nashef }\end{array}$ & R. Salamon & $\begin{array}{l}\text { European system for cardiac operative risk evaluation } \\
\text { (EuroSCORE) }\end{array}$ & $\begin{array}{l}\text { Papworth } \\
\text { Hospital }\end{array}$ & England \\
\hline 6 & 78.75 & $\begin{array}{l}\text { RB. } \\
\text { Rutherford }\end{array}$ & DN. Jones & $\begin{array}{l}\text { Recommended standards for reports dealing with lower } \\
\text { extremity ischemia: Revised version }\end{array}$ & $\begin{array}{l}\text { University of } \\
\text { Colorado }\end{array}$ & USA \\
\hline 7 & 75.33 & $\begin{array}{l}\text { NE. } \\
\text { Seymour }\end{array}$ & RM. Satava & $\begin{array}{l}\text { Virtual reality training improves operating room } \\
\text { performance-Results of a randomized, double-blinded } \\
\text { study }\end{array}$ & $\begin{array}{l}\text { Yale University } \\
\text { School of } \\
\text { Medicine }\end{array}$ & USA \\
\hline 8 & 71.10 & L. Norgren & CD. Liapis & $\begin{array}{l}\text { Inter-society consensus for the management of peripheral } \\
\text { arterial disease (TASC II) }\end{array}$ & $\begin{array}{l}\text { Orebro } \\
\quad \text { University }\end{array}$ & Sweden \\
\hline 9 & 66.44 & M. Lacroix & R. Sawaya & $\begin{array}{l}\text { A multivariate analysis of } 416 \text { patients with glioblastoma } \\
\text { multiforme: prognosis, extent of resection, and survival }\end{array}$ & $\begin{array}{l}\text { The University of } \\
\text { Texas }\end{array}$ & USA \\
\hline 10 & 61.40 & MN. Wente & $\begin{array}{l}\text { MW. } \\
\text { Buechler }\end{array}$ & $\begin{array}{l}\text { Delayed gastric emptying (DGE) after pancreatic surgery: a } \\
\text { suggested definition by the International Study Group of } \\
\text { Pancreatic Surgery (ISGPS) }\end{array}$ & $\begin{array}{r}\text { University of } \\
\text { Heidelberg }\end{array}$ & Germany \\
\hline
\end{tabular}

Over the intervening three and a half centuries, journals have established conventions for publication; insisting on independent (and usually anonymous) peer review of submissions, intended to preserve the integrity of the scientific process, but have come under increasing recent scrutiny. This bibliometric and Altmetric analysis is the first of its kind to identify the authors and themes that have had the greatest impact within the global arena of surgery. Several different pathological conditions and surgical interventions were included within this diverse field, as demonstrated by the top 100 articles relating to some six different anatomical and physiological systems and subject areas. A surprising finding was that no correlation was found between citation number and level of evidence, as defined by objective evidence based medicine references, which may seem counterintuitive, yet likely represents the challenge of linking impact with citation and research quality. Altmetric scores represent the latest emerging development and, in a decade or less, have clearly had significant impact because AS was significantly associated with both citation number and citation rate.

Citation rates were higher for recently published articles, which imply that these will become more influential clinically within the next 5-10 years. Influential articles are more likely to be cited by the scientific community, and these citations form the basis of the impact factor; which quantifies the average citations of the articles published within the journal during a specific period. Journals with a higher impact factor are recognised as being of a higher quality and more likely to contain influential articles. The majority of articles were published in journals with an impact factor of less than 5.7. Annals of Surgery published the most articles ranked within the upper $100(n=32)$ and has historically been the surgical journal ranked highest with an impact factor of 8.7. Journals with high-impact factors (54.42-29.35), NEJM, Lancet, JAMA, and Nature Genetics, were not represented in this analysis, yet the citations accrued by the articles identified were similar to those reported in other bibliometric analyses; colorectal cancer (7850-989) [109], gastric cancer (2893-299) [4], and oesophageal cancer (1833-293) [110]. A possible explanation relates to the novelty of the results, which may be classified relating to the scientific community in general, or confined to the field studied. Findings already reported in other arenas may then be re-established in the arena of surgery, and such articles are unlikely to be published in 
Table 4 Top 10 articles with the highest Altmetric score

\begin{tabular}{|c|c|c|c|c|c|c|}
\hline Rank & $\begin{array}{l}\text { Altmetric } \\
\text { score }\end{array}$ & First author & Senior author & Title & Institution & Country \\
\hline 1 & 53.0 & $\begin{array}{l}\text { WG, } \\
\text { Bigelow }\end{array}$ & $\begin{array}{l}\text { WF, } \\
\text { Greenwood }\end{array}$ & $\begin{array}{l}\text { Hypothermia-Its possible role in cardiac } \\
\text { surgery-An investigation of factors governing } \\
\text { survival in dogs at low body temperatures }\end{array}$ & University of Toronto & Canada \\
\hline 2 & 30.0 & NV, Christou & LD, MacLean & $\begin{array}{l}\text { Surgery decreases long-term mortality, morbidity, } \\
\text { and health care use in morbidly obese patients. }\end{array}$ & McGill University & Canada \\
\hline 3 & 25.0 & B, & F, Pott & $\begin{array}{l}\text { Effects of intravenous fluid restriction on } \\
\text { postoperative complications: comparison of two } \\
\text { perioperative fluid regimens: a randomized } \\
\text { assessor-blinded multicenter trial }\end{array}$ & $\begin{array}{l}\text { H:S Bispebjerg } \\
\text { University Hospital }\end{array}$ & Denmark \\
\hline 4 & 22.0 & $\begin{array}{l}\text { RM, } \\
\text { Rosenfeld }\end{array}$ & DL, Witsell & Clinical practice guideline: adult sinusitis & $\begin{array}{l}\text { SUNY Downstate } \\
\text { Medical Center and } \\
\text { Long Island College } \\
\text { Hospital }\end{array}$ & USA \\
\hline 5 & 22.0 & L, Norgren & FGR, Fowkes & $\begin{array}{l}\text { Inter-society consensus for the management of } \\
\text { peripheral arterial disease (TASC II) }\end{array}$ & Orebro University & Sweden \\
\hline 6 & 22.0 & L, Norgren & CD, Liapis & $\begin{array}{l}\text { Inter-society consensus for the management of } \\
\text { peripheral arterial disease (TASC II) }\end{array}$ & Orebro University & Sweden \\
\hline 7 & 17.0 & PA, Clavien & M, Makuuchi & $\begin{array}{l}\text { The Clavien-Dindo Classification of Surgical } \\
\text { Complications Five-Year Experience }\end{array}$ & $\begin{array}{l}\text { University Hospital of } \\
\text { Zurich }\end{array}$ & Switzerland \\
\hline 8 & 16.0 & $\begin{array}{l}\text { NE, } \\
\text { Seymour }\end{array}$ & RM, Satva & $\begin{array}{l}\text { Virtual reality training improves operating room } \\
\text { performance-Results of a randomized, double- } \\
\text { blinded study }\end{array}$ & $\begin{array}{l}\text { Yale University School } \\
\text { of Medicine }\end{array}$ & USA \\
\hline 9 & 14.0 & EH, Oldfield & NJ, Patronas & $\begin{array}{l}\text { Pathophysiology of syringomyelia associated with } \\
\text { Chiari I malformation of the cerebellar } \\
\text { tonsils-Implications for diagnosis and } \\
\text { treatment }\end{array}$ & $\begin{array}{l}\text { National Institute of } \\
\text { Neurological } \\
\text { Disorders and Stroke }\end{array}$ & USA \\
\hline 10 & 12.0 & SF, Khuri & JF, Stemple & $\begin{array}{l}\text { The Department of Veterans Affairs' NSQIP: the } \\
\text { first national, validated, outcome-based, risk- } \\
\text { adjusted, and peer-controlled program for the } \\
\text { measurement and enhancement of the quality of } \\
\text { surgical care. National VA Surgical Quality } \\
\text { Improvement Program }\end{array}$ & $\begin{array}{l}\text { Brockton/West } \\
\text { Roxbury VA Medical } \\
\text { Center }\end{array}$ & USA \\
\hline
\end{tabular}

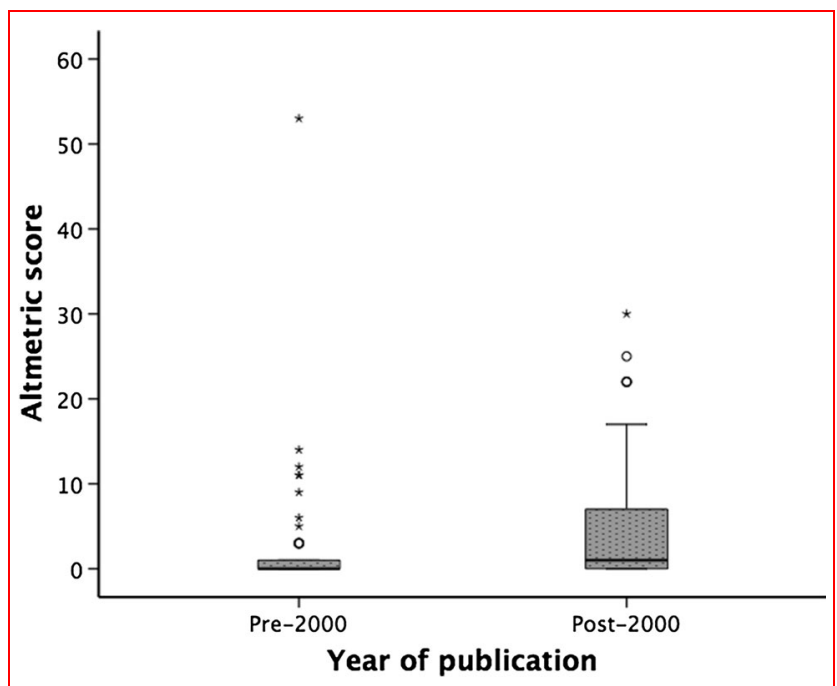

Fig. 2 The distribution of Altmetric scores in articles published pre- and post-2000. *Kruskal-Wallis test $p=0.018$ high-impact scientific journals, yet within the context of this study, remain likely to be considered influential.

There are a number of potential limitations inherent within this study related to several types of bias, which may confound the results. Disproportionate multiple citations may result from institutional bias, self-citation, powerful person, or language bias. Geographically, the high rate of publications from the USA has been reported previously [4, 5], arguably reflecting a preference by USA institutions to cite research performed locally. This effect may have been amplified by limiting the search to Englishlanguage articles. Moreover, older articles have a greater citation potential simply because of the length of time they have been in the public domain, rather than representing a true measure of impact. In an attempt to control for this, the number of citations was divided by the number of years since publication: a citation rate index. Despite these measures, the lead-time for publication of citing articles 


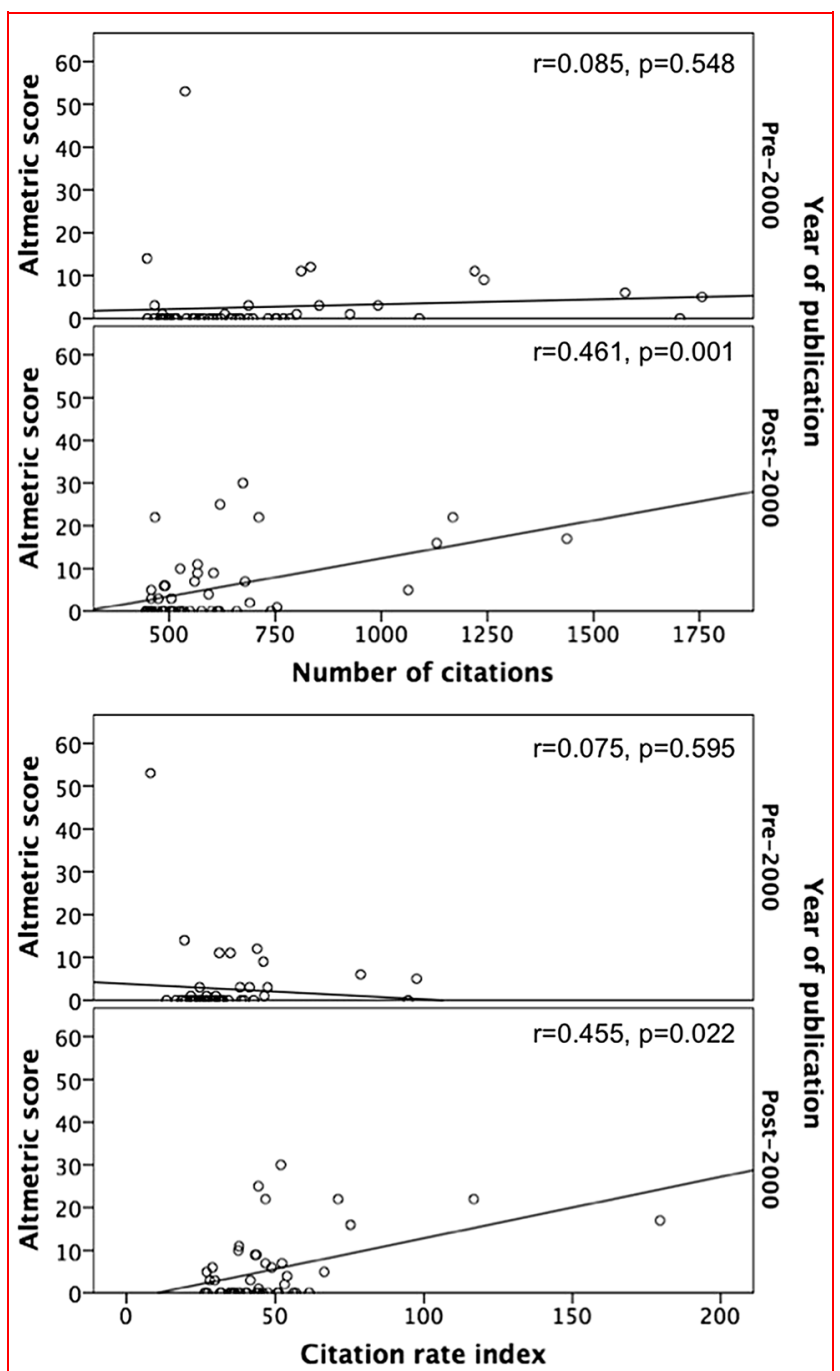

Fig. 3 The relationship between Altmetric score, number of citations, citation rate index stratified by pre- and post-2000 publication

may still result in under representation of more recent articles. The inclusion of only first and senior authors and the institution of the first author is also a possible limitation of the study, as it is possible that several first authors may have co-authored other articles, and are therefore under represented. The search terms used also represent an inherent weakness associated with interrogating bibliographic repositories, in that no combination of search terms is perfect. To identifying all papers relevant to surgery would arguably require an almost infinite number of search terms, which is not pragmatic. While the relative limitation of the search term 'surgery' is acknowledged, it is unlikely that this methodology has had a material effect on the ability of the study to address the a priori hypotheses. In contrast, the study has strengths. The many-landmark, randomized trials of surgical procedures, published in scientific and general medical journals, were included by the search methodology, which included the search term surgery, and encompassed non-surgical journals such as Nature, Science, NEJM, and the Lancet. The use of the search term surgery, more so than procedure or intervention, ensures that the results retain relevance to the field of surgery.

Another role that academic journals have come to play, and not part of their original job-description of disseminating scientific results, is as a marker of a researcher's prowess, and thus a surrogate determinant of academic career potential. Publication in a blue-chip title such as Nature or Science, without question represents a feather in the cap of any clinician, and therefore unlikely to be overlooked by any academically focused appointment committee. An article's true quality is better revealed by the number of times it is cited elsewhere (ideally not selfcitation), but citations take time to accumulate, and other, faster assessment means would be welcome, which has inevitably led to the development of alternative metrics in this regard, now termed "altimetry". These extend the concept of citation beyond references in other scientific papers; by recording, for example, how often a paper is downloaded, or when the outcome of a clinical trial is used to develop guidelines for doctors, or if a piece of work is included in a course curriculum. Altmetric.com, based in London, was one of the first companies to work in this area, and since 2011, it has tracked mentions of published papers in sources ranging from social media and Wikipedia, to policy documents published by government departments. A rival firm, Plum Analytics, in Philadelphia, tracks mentions, downloads, clicks and the like, of everything from preprints (papers that have been made publicly available, but are not yet formally published), and sets of raw data, to non-commercial computer programs which investigators have written to assist their own endeavours. Using Altmetrics should therefore indicate the importance of a wider range of research-related activities than citations provide, and moreover, do so faster. Plum Analytics was bought by Elsevier in 2017, one of the world's largest scientific publishers; suggesting that Altmetrics may also prove profitable, as well as useful.

Findings of medical research have long been considered to be disseminated too slowly, but that is about to change. In January 2017 the Gates Foundation introduced a policy, that research it supports (it is the world's biggest source of charitable money for scientific endeavours, to the tune of some $\$ 4 \mathrm{bn}$ a year) must, when published, be available to all, and followed this by announcing that it will foot the cost of placing such research in one repository of freely available articles, meaning that Gates-sponsored research cannot be invoiced. Such a manoeuvre would carry the caveat that recipients of Gates' financial support can no 
longer offer their output to journals such as Nature, or the New England Journal of Medicine, since accessing the content of these publications has associated cost. Their prestige is based on their ability to pick and publish only the best. If some work is out of bounds to these journals, no matter how good, that will risk diminishing their quality, and arguably those journals' businesses could suffer and even crumble. Moreover, by actively directing the beneficiaries of its patronage towards the repository in question, set up last year by the Wellcome Trust (after Gates, the world's second-largest medical research charity), the foundation is pointing to a specific type of alternative, and a future scientific publication arena that, if not completely journal-free, is likely journal-light.

\section{Conclusion}

This list of the top-cited articles in surgery has worth for a number of reasons. It identifies seminal contributions, facilitates the understanding and development of contemporary surgical history; and offers clues regarding what makes an article a likely top-cited classic. To produce such a work, the author or research group must come up with a clinical or nonclinical innovation, observation, or discovery that has a potential long-standing effect on surgical clinical practice. Based on the findings of this study, to be rewarded by citation number, such a scholarly contribution should be published in a high-impact journal, is more likely to be amplified and resonate loudly if it originates from an Anglo-Saxon academic institute, and in view of the dissonance regarding level of evidence, needs to be noticed by surgeons active on social media, implying a deal of good fortune is required. Recent studies have identified Twitter as the most commonly used smartphone application by surgeons, but the rates of engagement are variable between medical specialties; for example colorectal surgeons' engagement levels lag behind other disciplines. In 2014, only $31 \%$ of UK consultant colorectal surgeons were found to have Twitter profiles, compared with higher engagement rates within other surgical sub-specialties such as urology $(33 \%)$, plastic surgery $(22 \%)$ and vascular surgery $(5 \%)$ [111]. To make any best seller list has now become that much more challenging.

Open Access This article is distributed under the terms of the Creative Commons Attribution 4.0 International License (http://crea tivecommons.org/licenses/by/4.0/), which permits unrestricted use, distribution, and reproduction in any medium, provided you give appropriate credit to the original author(s) and the source, provide a link to the Creative Commons license, and indicate if changes were made.

\section{References}

1. Murray MR, Wang T, Schroeder GD, Hsu WK (2012) The100 most cited spine articles. Eur Spine J 21:2059-2069

2. Kelly JC, Glynn RW, O’Briain DE, Felle P, McCabe JP (2010) The 100 classic papers of orthopaedic surgery: a bibliometric analysis. J Bone Joint Surg Br 92:1338-1343

3. Paladugu R, Schein M, Gardezi S, Wise L (2002) One hundred citation classics in general surgical journals. World J Surg 260:1099-1105. https://doi.org/10.1007/s00268-002-6376-7

4. Powell AG, Hughes DL, Wheat JR, Lewis WG (2016) The 100 most influential manuscripts in gastric cancer: a bibliometric analysis. Int J Surg 28:83-90

5. Ellul T, Bullock N, Abdelrahman T, Powell AGMT, Witherspoon J, Lewis WG (2016) The 100 most cited manuscripts in emergency abdominal surgery: a bibliometric analysis. Int $\mathbf{J}$ Surg 37:29-35

6. Tas F (2014) An analysis of the most-cited research papers on oncology: which journals have they been published in? Tumour Biol 35:4645-4649

7. Sackett DL (1989) Rules of evidence and clinical recommendations on the use of antithrombotic agents. Chest 95:2S-4S

8. CEBM (2017) Oxford centre for evidence based medicine, 2017. http://www.cebm.net. Accessed 1 May 2017

9. Dindo D, Demartines N, Clavien PA (2004) Classification of surgical complications: a new proposal with evaluation in a cohort of 6336 patients and results of a survey. Ann Surg 240:205-213

10. Fong Y, Fortner J, Sun RL, Brennan MF, Blumgart LH (1999) Clinical score for predicting recurrence after hepatic resection for metastatic colorectal cancer: analysis of 1001 consecutive cases. Ann Surg 230:309-318

11. Nashef SA, Roques F, Michel P, Gauducheau E, Lemeshow S, Salamon R (1999) European system for cardiac operative risk evaluation (EuroSCORE). Eur J Cardiothorac Surg 16:9-13

12. Rutherford RB, Baker JD, Ernst C, Johnston KW, Porter JM, Ahn S, Jones DN (1997) Recommended standards for reports dealing with lower extremity ischemia: revised version. J Vasc Surg 26:517-538

13. Clavien PA, Barkun J, de Oliveira ML, Vauthey JN, Dindo D, Schulick RD, de Santibañes E, Pekolj J, Slankamenac K, Bassi C, Graf R, Vonlanthen R, Padbury R, Cameron JL, Makuuchi M (2009) The Clavien-Dindo classification of surgical complications: five-year experience. Ann Surg 250:187-196

14. Kassell NF, Torner JC, Haley EC Jr, Jane JA, Adams HP, Kongable GL (1990) The international cooperative study on the timing of aneurysm surgery. part 1: overall management results. J Neurosurg 73:18-36

15. Heald RJ, Husband EM, Ryall RD (1982) The mesorectum in rectal cancer surgery-the clue to pelvic recurrence? Br J Surg 69:613-616

16. Norgren L, Hiatt WR, Dormandy JA, Nehler MR, Harris KA, Fowkes FG, TASC II Working Group (2007) Inter-society consensus for the management of peripheral arterial disease (TASC II). J Vasc Surg 45(Suppl S):S5-S67

17. Seymour NE, Gallagher AG, Roman SA, O'Brien MK, Bansal VK, Andersen DK, Satava RM (2002) Virtual reality training improves operating room performance: results of a randomized, double-blinded study. Ann Surg 236:458-463

18. Carpentier A (1983) Cardiac valve surgery-the "French correction". J Thorac Cardiovasc Surg 86:323-337

19. Lacroix M, Abi-Said D, Fourney DR, Gokaslan ZL, Shi W, DeMonte F, Lang FF, McCutcheon IE, Hassenbusch SJ, Holland E, Hess K, Michael C, Miller D, Sawaya R (2001) A multivariate analysis of 416 patients with glioblastoma multiforme: 
prognosis, extent of resection, and survival. J Neurosurg 95:190-198

20. Krag DN, Weaver DL, Alex JC, Fairbank JT (1993) Surgical resection and radiolocalization of the sentinel lymph node in breast cancer using a gamma probe. Surg Oncol 2:335-339

21. Martin JA, Regehr G, Reznick R, MacRae H, Murnaghan J, Hutchison C, Brown M (1997) Objective structured assessment of technical skill (OSATS) for surgical residents. Br J Surg 84:273-278

22. Roques F, Nashef SA, Michel P, Gauducheau E, de Vincentiis C, Baudet E, Cortina J, David M, Faichney A, Gabrielle F, Gams E, Harjula A, Jones MT, Pintor PP, Salamon R, Thulin L (1999) Risk factors and outcome in European cardiac surgery: analysis of the EuroSCORE multinational database of 19030 patients. Eur J Cardiothorac Surg 15:816-822

23. Khuri SF, Daley J, Henderson W, Hur K, Demakis J, Aust JB, Chong V, Fabri PJ, Gibbs JO, Grover F, Hammermeister K, Irvin G 3rd, McDonald G, Passaro E Jr, Phillips L, Scamman F, Spencer J, Stremple JF (1998) The Department of Veterans Affairs' NSQIP: the first national, validated, outcome-based, risk-adjusted, and peer controlled program for the measurement and enhancement of the quality of surgical care. National VA Surgical Quality Improvement Program. Ann Surg 228:491-507

24. Guglielmi G, Viñuela F, Dion J, Duckwiler G (1991) Electrothrombosis of saccular aneurysms via endovascular approach. Part 2: preliminary clinical experience. J Neurosurg 75:8-14

25. Earlam R, Cunha-Melo JR (1980) Oesophageal squamous cell carcinoma: I. A critical review of surgery. Br J Surg 67:381-390

26. Laitinen LV, Bergenheim AT, Hariz MI (1992) Leksell's posteroventral pallidotomy in the treatment of Parkinson's disease. J Neurosurg 76:53-61

27. Curley SA, Izzo F, Delrio P, Ellis LM, Granchi J, Vallone P, Fiore F, Pignata S, Daniele B, Cremona F (1999) Radiofrequency ablation of unresectable primary and metastatic hepatic malignancies: results in 123 patients. Ann Surg 230:1-8

28. Schauer PR, Ikramuddin S, Gourash W, Ramanathan R, Luketich J (2000) Outcomes after laparoscopic Roux-en-Y gastric bypass for morbid obesity. Ann Surg 232:515-529

29. Porter JM, Moneta GL (1995) Reporting standards in venous disease: an update. International Consensus Committee on Chronic Venous Disease. J Vasc Surg 21:635-645

30. Heald RJ, Moran BJ, Ryall RD, Sexton R, MacFarlane JK (1998) Rectal cancer: the Basingstoke experience of total mesorectal excision, 1978-1997. Arch Surg 133:894-899

31. Adam R, Delvart V, Pascal G, Valeanu A, Castaing D, Azoulay D, Giacchetti S, Paule B, Kunstlinger F, Ghémard O, Levi F, Bismuth H (2004) Rescue surgery for unresectable colorectal liver metastases downstaged by chemotherapy: a model to predict long-term survival. Ann Surg 240:644-657

32. Siewert JR, Böttcher K, Stein HJ, Roder JD (1998) Relevant prognostic factors in gastric cancer: ten-year results of the German Gastric Cancer Study. Ann Surg 228:449-461

33. Norgren L, Hiatt WR, Dormandy JA, Nehler MR, Harris KA, Fowkes FG, TASC II Working Group, Bell K, Caporusso J, Durand-Zaleski I, Komori K, Lammer J, Liapis C, Novo S, Razavi M, Robbs J, Schaper N, Shigematsu H, Sapoval M, White C, White J, Clement D, Creager M, Jaff M, Mohler E 3rd, Rutherford RB, Sheehan P, Sillesen H, Rosenfield K (2007) Inter-society consensus for the management of peripheral arterial disease (TASC II). Eur J Vasc Endovasc Surg 33(Suppl 1):S1-S75

34. Svensson LG, Crawford ES, Hess KR, Coselli JS, Safi HJ (1993) Experience with 1509 patients undergoing thoracoabdominal aortic operations. J Vasc Surg 17:357-368

35. Galatz LM, Ball CM, Teefey SA, Middleton WD, Yamaguchi K (2004) The outcome and repair integrity of completely arthroscopically repaired large and massive rotator cuff tears. J Bone Joint Surg Am 86-A:219-224

36. Klinkenbijl JH, Jeekel J, Sahmoud T, van Pel R, Couvreur ML, Veenhof CH, Arnaud JP, Gonzalez DG, de Wit LT, Hennipman A, Wils J (1999) Adjuvant radiotherapy and 5-fluorouracil after curative resection of cancer of the pancreas and periampullary region: phase III trial of the EORTC gastrointestinal tract cancer cooperative group. Ann Surg 230:776-782

37. Fazio VW, Ziv Y, Church JM et al (1995) Ileal pouch-anal anastomoses complications and function in 1005 patients. Ann Surg 222:120-127

38. Eklöf B, Rutherford RB, Bergan JJ, Carpentier PH, Gloviczki P, Kistner RL, Meissner MH, Moneta GL, Myers K, Padberg FT, Perrin M, Ruckley CV, Smith PC, Wakefield TW, American Venous Forum International Ad Hoc Committee for Revision of the CEAP Classification (2004) Revision of the CEAP classification for chronic venous disorders: consensus statement. J Vasc Surg 40:1248-1252

39. Christou NV, Sampalis JS, Liberman M et al (2004) Surgery decreases long-term mortality, morbidity, and health care use in morbidly obese patients. Ann Surg 240:416-424

40. Arrington ED, Smith WJ, Chambers HG, Bucknell AL, Davino NA (1996) Complications of iliac crest bone graft harvesting. Clin Orthop Relat Res 329:300-309

41. Benabid AL, Pollak P, Gao D, Hoffmann D, Limousin P, Gay E, Payen I, Benazzouz A (1996) Chronic electrical stimulation of the ventralis intermedius nucleus of the thalamus as a treatment of movement disorders. J Neurosurg 84:203-214

42. Knutsen G, Drogset JO, Engebretsen L, Grøntvedt T, Isaksen V, Ludvigsen TC, Roberts S, Solheim E, Strand T, Johansen O (2007) A randomized trial comparing autologous chondrocyte implantation with microfracture. Findings at five years. J Bone Joint Surg Am 89:2105-2112

43. Strasberg SM, Hertl M, Soper NJ (1995) An analysis of the problem of biliary injury during laparoscopic cholecystectomy. J Am Coll Surg 180:101-125

44. Viñuela F, Duckwiler G, Mawad M (1997) Guglielmi detachable coil embolization of acute intracranial aneurysm: perioperative anatomical and clinical outcome in 403 patients. J Neurosurg 86:475-482

45. Rosenberg SA, Tepper J, Glatstein E et al (1982) The treatment of soft-tissue sarcomas of the extremities: prospective randomized evaluations of (1) limb-sparing surgery plus radiation therapy compared with amputation and (2) the role of adjuvant chemotherapy. Ann Surg 196:305-315

46. Bismuth H, Adam R, Lévi F et al (1996) Resection of nonresectable liver metastases from colorectal cancer after neoadjuvant chemotherapy. Ann Surg 224:509-522

47. Clavien PA, Sanabria JR, Strasberg SM (1992) Proposed classification of complications of surgery with examples of utility in cholecystectomy. Surgery 111:518-526

48. Brandstrup B, Tønnesen H, Beier-Holgersen R, Hjorts $\varnothing$ E, Ørding H, Lindorff-Larsen K, Rasmussen MS, Lanng C, Wallin L, Iversen LH, Gramkow CS, Okholm M, Blemmer T, Svendsen PE, Rottensten HH, Thage B, Riis J, Jeppesen IS, Teilum D, Christensen AM, Graungaard B, Pott F, Danish Study Group on Perioperative Fluid Therapy (2003) Effects of intravenous fluid restriction on postoperative complications: comparison of two perioperative fluid regimens: a randomized assessor-blinded multicenter trial. Ann Surg 238:641-648

49. Ethgen O, Bruyère O, Richy F, Dardennes C, Reginster JY (2004) Health-related quality of life in total hip and total knee arthroplasty. A qualitative and systematic review of the literature. J Bone Joint Surg Am 86:963-974

50. Wente MN, Bassi C, Dervenis C, Fingerhut A, Gouma DJ, Izbicki JR, Neoptolemos JP, Padbury RT, Sarr MG, Traverso 
LW, Yeo CJ, Büchler MW (2007) Delayed gastric emptying (DGE) after pancreatic surgery: a suggested definition by the International Study Group of Pancreatic Surgery (ISGPS). Surgery 142:761-768

51. Buzby GP, Mullen JL, Matthews DC, Hobbs CL, Rosato EF (1980) Prognostic nutritional index in gastrointestinal surgery. Am J Surg 139:160-167

52. Schauer PR, Burguera B, Ikramuddin S et al (2003) Effect of laparoscopic Roux-En Y gastric bypass on type 2 diabetes mellitus. Ann Surg 238:467-485

53. Kassell NF, Torner JC, Jane JA, Haley EC Jr, Adams HP (1990) The International Cooperative Study on the Timing of Aneurysm Surgery. Part 2: surgical results. J Neurosurg 73:37-47

54. Kehlet H, Wilmore DW (2002) Multimodal strategies to improve surgical outcome. Am J Surg 183:630-641

55. Butler J, Rocker GM, Westaby S (1993) Inflammatory response to cardiopulmonary bypass. Ann Thorac Surg 55:552-559

56. Chen MS, Li JQ, Zheng Y et al (2006) A prospective randomized trial comparing percutaneous local ablative therapy and partial hepatectomy for small hepatocellular carcinoma. Ann Surg 243:321-328

57. Furnary AP, Zerr KJ, Grunkemeier GL, Starr A (1999) Continuous intravenous insulin infusion reduces the incidence of deep sternal wound infection in diabetic patients after cardiac surgical procedures. Ann Thorac Surg 67:352-360

58. Nguyen NT, Goldman C, Rosenquist CJ, Arango A, Cole CJ, Lee SJ, Wolfe BM (2001) Laparoscopic versus open gastric bypass: a randomized study of outcomes, quality of life, and costs. Ann Surg 234:279-289

59. Cooper JD, Trulock EP, Triantafillou AN, Patterson GA, Pohl MS, Deloney PA, Sundaresan RS, Roper CL (1995) Bilateral pneumectomy (volume reduction) for chronic obstructive pulmonary disease. J Thorac Cardiovasc Surg 109:106-116

60. Grantcharov TP, Kristiansen VB, Bendix J, Bardram L, Rosenberg J, Funch-Jensen P (2004) Randomized clinical trial of virtual reality simulation for laparoscopic skills training. $\mathrm{Br} \mathrm{J}$ Surg 91:146-150

61. Sharkey PF, Lichstein PM, Shen C, Tokarski AT, Parvizi J (2014) Why are total knee arthroplasties failing today-has anything changed after 10 years? J Arthroplasty 29:1774-1778

62. Willert HG, Buchhorn GH, Fayyazi A, Flury R, Windler M, Köster G, Lohmann CH (2005) Metal-on-metal bearings and hypersensitivity in patients with artificial hip joints. A clinical and histomorphological study. J Bone Joint Surg Am 87:28-36

63. Maruyama K, Okabayashi K, Kinoshita T (1987) Progress in gastric cancer surgery in Japan and its limits of radicality. World J Surg 11:418-425. https://doi.org/10.1007/BF01655804

64. Fong Y, Sun RL, Jarnagin W, Blumgart LH (1999) An analysis of 412 cases of hepatocellular carcinoma at a Western center. Ann Surg 229:790-799

65. Luce DA (2005) Determining in vivo biomechanical properties of the cornea with an ocular response analyzer. J Cataract Refract Surg 31:156-162

66. Dworak O, Keilholz L, Hoffmann A (1997) Pathological features of rectal cancer after preoperative radiochemotherapy. Int J Colorectal Dis 12:19-23

67. Bigelow WG, Lindsay WK, Greenwood WF (1950) Hypothermia: its possible role in cardiac surgery: an investigation of factors governing survival in dogs at low body temperatures. Ann Surg 132:849-866

68. Rockwood TH, Church JM, Fleshman JW, Kane RL, Mavrantonis C, Thorson AG, Wexner SD, Bliss D, Lowry AC (2000) Fecal incontinence quality of life scale: quality of life instrument for patients with fecal incontinence. Dis Colon Rectum 43:9-16

69. Jenkins KJ, Gauvreau K, Newburger JW, Spray TL, Moller JH, Iezzoni LI (2002) Consensus-based method for risk adjustment for surgery for congenital heart disease. $\mathrm{J}$ Thorac Cardiovasc Surg 123:110-118

70. Steadman JR, Briggs KK, Rodrigo JJ, Kocher MS, Gill TJ, Rodkey WG (2003) Outcomes of microfracture for traumatic chondral defects of the knee: average 11-year follow-up. Arthroscopy 19:477-484

71. Pawlik TM, Scoggins CR, Zorzi D, Abdalla EK, Andres A, Eng C, Curley SA, Loyer EM, Muratore A, Mentha G, Capussotti L, Vauthey JN (2005) Effect of surgical margin status on survival and site of recurrence after hepatic resection for colorectal metastases. Ann Surg 241:715-722

72. Reznick R, Regehr G, MacRae H, Martin J, McCulloch W (1997) Testing technical skill via an innovative "bench station" examination. Am J Surg 173:226-230

73. Morton DL, Thompson JF, Essner R, Elashoff R, Stern SL, Nieweg OE, Roses DF, Karakousis CP, Mozzillo N, Reintgen D, Wang HJ, Glass EC, Cochran AJ (1999) Validation of the accuracy of intraoperative lymphatic mapping and sentinel lymphadenectomy for early-stage melanoma: a multicenter trial. Multicenter Selective Lymphadenectomy Trial Group. Ann Surg 230:453-463

74. Creswell LL, Schuessler RB, Rosenbloom M, Cox JL (1993) Hazards of postoperative atrial arrhythmias. Ann Thorac Surg 56:539-549

75. Enker WE, Thaler HT, Cranor ML, Polyak T (1995) Total mesorectal excision in the operative treatment of carcinoma of the rectum. J Am Coll Surg 181:335-346

76. Marescaux J, Dallemagne B, Perretta S, Wattiez A, Mutter D, Coumaros D (2007) Surgery without scars: report of transluminal cholecystectomy in a human being. Arch Surg 142:823-826

77. Burkhart SS, De Beer JF (2000) Traumatic glenohumeral bone defects and their relationship to failure of arthroscopic Bankart repairs: significance of the inverted-pear glenoid and the humeral engaging Hill-Sachs lesion. Arthroscopy 16:677-694

78. Kehlet H, Wilmore DW (2008) Evidence-based surgical care and the evolution of fast-track surgery. Ann Surg 248:189-198

79. Cheville JC, Lohse CM, Zincke H, Weaver AL, Blute ML (2003) Comparisons of outcome and prognostic features among histologic subtypes of renal cell carcinoma. Am J Surg Pathol 27:612-624

80. Borgstein PJ, Pijpers R, Comans EF, van Diest PJ, Boom RP, Meijer S (1998) Sentinel lymph node biopsy in breast cancer: guidelines and pitfalls of lymphoscintigraphy and gamma probe detection. J Am Coll Surg 186:275-283

81. Ciric I, Ragin A, Baumgartner C, Pierce D (1997) Complications of transsphenoidal surgery: results of a national survey, review of the literature, and personal experience. Neurosurgery. 40:225-236

82. Wittgrove AC, Clark GW (2000) Laparoscopic gastric bypass, Roux-en-Y- 500 patients: technique and results, with 3-60 month follow-up. Obes Surg 10:233-239

83. Black PM, Moriarty T, Alexander E 3rd, Stieg P, Woodard EJ, Gleason PL, Martin CH, Kikinis R, Schwartz RB, Jolesz FA (1997) Development and implementation of intraoperative magnetic resonance imaging and its neurosurgical applications. Neurosurgery. 41:831-842

84. Peeters KC, Marijnen CA, Nagtegaal ID, Kranenbarg EK, Putter $\mathrm{H}$, Wiggers T, Rutten H, Pahlman L, Glimelius B, Leer JW, van de Velde CJ, Dutch Colorectal Cancer Group (2007) The TME trial after a median follow-up of 6 years: increased local control but no survival benefit in irradiated patients with resectable rectal carcinoma. Ann Surg 246:693-701

85. Rattner D, Kalloo A, ASGE/SAGES Working Group (2006) ASGE/SAGES working group on natural orifice translumenal endoscopic surgery. October 2005. Surg Endosc 20:329-333 
86. Bernier J, Cooper JS, Pajak TF, van Glabbeke M, Bourhis J, Forastiere A, Ozsahin EM, Jacobs JR, Jassem J, Ang KK, Lefèbvre JL (2005) Defining risk levels in locally advanced head and neck cancers: a comparative analysis of concurrent postoperative radiation plus chemotherapy trials of the EORTC (\#22931) and RTOG (\# 9501). Head Neck 27:843-850

87. Edmunds LH Jr, Clark RE, Cohn LH, Grunkemeier GL, Miller DC, Weisel RD (1996) Guidelines for reporting morbidity and mortality after cardiac valvular operations. Eur J Cardiothorac Surg 10:812-816

88. Slim K, Nini E, Forestier D, Kwiatkowski F, Panis Y, Chipponi J (2003) Methodological index for non-randomized studies (minors): development and validation of a new instrument. ANZ J Surg 73:712-716

89. Lytle BW, Blackstone EH, Loop FD, Houghtaling PL, Arnold JH, Akhrass R, McCarthy PM, Cosgrove DM (1999) Two internal thoracic artery grafts are better than one. J Thorac Cardiovasc Surg 117:855-872

90. Conlon KC, Klimstra DS, Brennan MF (1996) Long-term survival after curative resection for pancreatic ductal adenocarcinoma. Clinicopathologic analysis of 5-year survivors. Ann Surg 223:273-279

91. Kajitani T (1981) The general rules for the gastric cancer study in surgery and pathology. Part I. Clinical classification. Jpn J Surg 11:127-139

92. Roumen RM, Hendriks T, van der Ven-Jongekrijg J, Nieuwenhuijzen GA, Sauerwein RW, van der Meer JW, Goris RJ (1993) Cytokine patterns in patients after major vascular surgery, hemorrhagic shock, and severe blunt trauma. Relation with subsequent adult respiratory distress syndrome and multiple organ failure. Ann Surg 218:769-776

93. Balcom JH 4th, Rattner DW, Warshaw AL, Chang Y, Fernandez-del Castillo C (2001) Ten-year experience with 733 pancreatic resections: changing indications, older patients, and decreasing length of hospitalization. Arch Surg 136:391-398

94. Habr-Gama A, Perez RO, Nadalin W, Sabbaga J, Ribeiro U Jr, Silva e Sousa AH Jr, Campos FG, Kiss DR, Gama-Rodrigues J (2004) Operative versus nonoperative treatment for stage 0 distal rectal cancer following chemoradiation therapy: long-term results. Ann Surg 240:711-717

95. Rosenfeld RM, Andes D, Bhattacharyya N, Cheung D, Eisenberg S, Ganiats TG, Gelzer A, Hamilos D, Haydon RC 3rd, Hudgins PA, Jones S, Krouse HJ, Lee LH, Mahoney MC, Marple BF, Mitchell CJ, Nathan R, Shiffman RN, Smith TL, Witsell DL (2007) Clinical practice guideline: adult sinusitis. Otolaryngol Head Neck Surg 137:S1-S31

96. Sosa JA, Bowman HM, Tielsch JM, Powe NR, Gordon TA, Udelsman R (1998) The importance of surgeon experience for clinical and economic outcomes from thyroidectomy. Ann Surg 228:320-330

97. Becker JM, Dayton MT, Fazio VW, Beck DE, Stryker SJ, Wexner SD, Wolff BG, Roberts PL, Smith LE, Sweeney SA, Moore M (1996) Prevention of postoperative abdominal adhesions by a sodium hyaluronate-based bioresorbable membrane: a prospective, randomized, double-blind multicenter study. J Am Coll Surg 183:297-306

98. Gerber C, Fuchs B, Hodler J (2000) The results of repair of massive tears of the rotator cuff. J Bone Joint Surg Am 82:505-515

99. Bierbaum BE, Callaghan JJ, Galante JO, Rubash HE, Tooms RE, Welch RB (1999) An analysis of blood management in patients having a total hip or knee arthroplasty. J Bone Joint Surg Am 81:2-10

100. le Roux CW, Aylwin SJ, Batterham RL, Borg CM, Coyle F, Prasad V, Shurey S, Ghatei MA, Patel AG, Bloom SR (2006) Gut hormone profiles following bariatric surgery favor an anorectic state, facilitate weight loss, and improve metabolic parameters. Ann Surg 243:108-114

101. Gouma DJ, van Geenen RC, van Gulik TM, de Haan RJ, de Wit LT, Busch OR, Obertop H (2000) Rates of complications and death after pancreaticoduodenectomy: risk factors and the impact of hospital volume. Ann Surg 232:786-795

102. Boileau P, Brassart N, Watkinson DJ, Carles M, Hatzidakis AM, Krishnan SG (2005) Arthroscopic repair of full-thickness tears of the supraspinatus: does the tendon really heal? J Bone Joint Surg Am 87:1229-1240

103. Huscher CG, Mingoli A, Sgarzini G, Sansonetti A, Di Paola M, Recher A, Ponzano C (2005) Laparoscopic versus open subtotal gastrectomy for distal gastric cancer: five-year results of a randomized prospective trial. Ann Surg 241:232-237

104. Zarins CK, White RA, Schwarten D, Kinney E, Diethrich EB, Hodgson KJ, Fogarty TJ (1999) AneuRx stent graft versus open surgical repair of abdominal aortic aneurysms: multicenter prospective clinical trial. J Vasc Surg 29:292-305

105. Oldfield EH, Muraszko K, Shawker TH, Patronas NJ (1994) Pathophysiology of syringomyelia associated with Chiari I malformation of the cerebellar tonsils. Implications for diagnosis and treatment. J Neurosurg 80:3-15

106. Hangody L, Füles P (2003) Autologous osteochondral mosaicplasty for the treatment of full-thickness defects of weightbearing joints: ten years of experimental and clinical experience. J Bone Joint Surg Am 85-A(Suppl 2):25-32

107. Minagawa M, Makuuchi M, Torzilli G et al (2000) Extension of the frontiers of surgical indications in the treatment of liver metastases from colorectal cancer: long-term results. Ann Surg 231:487-499

108. Kennedy DW, Zinreich SJ, Rosenbaum AE, Johns ME (1985) Functional endoscopic sinus surgery. Theory and diagnostic evaluation. Arch Otolaryngol 111:576-582

109. Wrafter PF, Connelly TM, Khan J, Devane L, Kelly J, Joyce WP (2016) The 100 most influential manuscripts in colorectal cancer: a bibliometric analysis. Surgeon 14:327-336

110. Powell AG, Hughes DL, Brown J, Larsen M, Witherspoon J, Lewis WG (2017) Esophageal cancer's 100 most influential manuscripts: a bibliometric analysis. Dis Esophagus 30:1-8

111. Brady RRW, Chapman SJ, Atallah S, Chand M, Mayol J, Lacy AM, Wexner SD (2017) \#colorectalsurgery. Br J Surg 104:1470-1476 